\title{
Review \\ Development of Organ-Preserving Radiation Therapy in Gastric Marginal Zone Lymphoma
}

\author{
Daniel Rolf $\left.{ }^{\dagger} \mathbb{(}\right)$, Gabriele Reinartz $\left.{ }^{+} \mathbb{(}\right)$, Stephan Rehn, Christopher Kittel and Hans Theodor Eich *
}

check for updates

Citation: Rolf, D.; Reinartz, G.; Rehn, S.; Kittel, C.; Eich, H.T. Development of Organ-Preserving Radiation Therapy in Gastric Marginal Zone Lymphoma. Cancers 2022, 14, 873. https://doi.org/10.3390/ cancers 14040873

Academic Editor: Markus Raderer

Received: 29 November 2021

Accepted: 28 January 2022

Published: 10 February 2022

Publisher's Note: MDPI stays neutral with regard to jurisdictional claims in published maps and institutional affiliations.

Copyright: (c) 2022 by the authors. Licensee MDPI, Basel, Switzerland. This article is an open access article distributed under the terms and conditions of the Creative Commons Attribution (CC BY) license (https:// creativecommons.org/licenses/by/ $4.0 /)$.

\author{
Department of Radiation Oncology, University Hospital of Münster, 48149 Münster, Germany; \\ daniel.rolf@ukmuenster.de (D.R.); gabriele.reinartz@ukmuenster.de (G.R.); stephan.rehn@ukmuenster.de (S.R.); \\ Christopher.Kittel@ukmuenster.de (C.K.) \\ * Correspondence: hans.eich@ukmuenster.de; Tel.: +49-251-83-47384; Fax: +49-251-83-47355 \\ + These authors contributed equally to this work.
}

Simple Summary: Gastric marginal zone lymphoma of the stomach is a rare cancer type primarily treated with oral proton pump inhibitors. If the disease does not respond to this, radiation is the treatment of choice. This review presents the development of radiation therapy over the last decades. Earlier, the stomach was surgically removed and irradiation was performed using large-field techniques and high doses of radiation. Currently, the standard treatment is the use of small-volume radiation therapy (with few side effects) with the preservation of the stomach, which provides excellent outcomes. In addition, this paper provides an outlook on current studies and possible future developments.

\begin{abstract}
Gastric marginal zone lymphoma (gMZL) of mucosa-associated lymphoid tissue (MALT) may persist even after H. pylori eradication, or it can be primarily Helicobacter pylori (H. pylori) independent. For patients without the successful eradication of lymphoma, or with progressive disease, treatment options have historically included partial or total gastrectomy. Presently, in these instances, curative radiation therapy (RT) is the current standard of care. This review emphasizes the historically changing role of radiation therapy in gMZL, progressing from large-volume RT without surgery, to localized RT, on its own, as a curative organ-preserving treatment. This overview shows the substantial progress in radiation therapy during the recent two to three decades, from high-dose, large-field techniques to low-dose, localized target volumes based on advanced imaging, three-dimensional treatment planning, and advanced treatment delivery techniques. RT has evolved from very large extended field techniques (EF) with prophylactic treatment of the whole abdomen and the supradiaphragmatic lymph nodes, applying doses between 30 and 50 Gy, to involved-field RT (IF), to the current internationally recommended involved site radiation therapy (ISRT) with a radiation dose of 24-30 Gy in gMZL. Stage-adapted RT is a highly effective and safe treatment with excellent overall survival rates and very rare acute or late treatment-related toxicities, as shown not only in retrospective studies, but also in large prospective multicenter studies, such as those conducted by the German Study Group on Gastrointestinal Lymphoma (DSGL). Further de-escalation of the radiation treatments with low-dose $20 \mathrm{~Gy}$, as well as ultra-low-dose $4 \mathrm{~Gy}$ radiation therapy, is under investigation within ongoing prospective clinical trials of the International Lymphoma Radiation Oncology Group (ILROG) and of the German Lymphoma Alliance (GLA).
\end{abstract}

Keywords: non-Hodgkin lymphoma; gastric marginal zone lymphoma; MALT lymphoma of the stomach; radiation therapy; ILROG

\section{Introduction}

Marginal zone lymphoma (MZL) of mucosa-associated lymphoid tissue (MALT) belongs to low-grade B-cell lymphomas [1]. It is the most common lymphoid neoplasm arising in the mucosa and was first described in 1983 by Isaacson [2]. According to the World 
Health Organization (WHO), three distinct, clinically different marginal zone lymphoma (MZL) entities have been described: extranodal MZL of MALT type (MALT lymphoma), splenic MZL, and nodal MZL [3]. Extranodal marginal zone lymphomas are most frequently located in the stomach (50-86\% of all cases). The most important risk factor for gastric MZL is Helicobacter pylori infection [3].

The incidence of gastric MZL (gMZL) has been increasing, and most patients present with early-stage disease. Possibly, this may be influenced by the development of advanced endoscopic ultrasound [1,4-6].

In H. pylori positive gMZL, eradication using antibiotics to remove microenvironmental stimuli supporting tumor growth results in lymphoma regression in 55.6-84.1\% of cases, and a long-term complete response in approximately $75 \%$ of cases $[7,8]$. For patients without the successful eradication of lymphoma, or with progressive disease, treatment options have historically included surgery, whereas the current treatment modalities are immunotherapy, chemotherapy (CTx), and radiation therapy (RT) [1,9-11].

The optimization of the treatment strategy for gMZL has a long history. Because of the rarity of gMZL ( 0.4 to 0.6 cases per 100,000 persons per year) [12], there are mainly retrospective studies reporting small patient numbers. These studies combine various types of gastric non-Hodgkin lymphoma (NHL) and employ different histologic classifications, staging systems, and forms of treatment.

Prior to the early 1990s, partial or total gastrectomy was the standard of care. This procedure is associated with significant morbidity and is currently rarely used as salvage treatment [13]. Despite the lack of evidence, the main concerns about using CTx and/or RT were gastric perforation or bleeding [2,14-19]. Over time, the information improved in favor of a solely organ-preserving therapy [14,15]. Early-stage disease patients treated with RT and/or CTx showed a low incidence of severe complications and a non-inferior outcome to Sx [14,16-24].

The most effective single modality for local control (LC) of most types of lymphoma is radiation therapy. The history of RT in treating lymphomas shows one of the greatest successes in modern cancer treatment [25]. Because of the excellent LC compared to Sx, RT has been widely used and is internationally recommended as the therapy of choice in localized stages of lymphoma [9,26-29]. Depending on the subtype of lymphoma, the remission rates exceed $95 \%$, but the recurrence rates increase with the length of the followup period. The recurrences are mainly localized or locoregional in the stomach or the duodenum [28-30].

From the 1960s to 1980s, the five-year overall survival rate using RT for gMZL was between 35 and 65\% [15,16,31]. Currently, gMZLpatients do not usually die of their lymphoma, but reach roughly the mean life expectancy of the normal population. At 15 years post-treatment, the median age of a cohort of 178 patients (Yahalom et al.) was 78.5 years, and the life expectancy of the US population is 78.6 years [30].

In the past, extensive RT of the whole abdomen (WART) resulted in good local control, but also in worrisome long-term morbidity [32,33]. This prompted a renewed examination of extensive RT: reduced extended (red. EF) and involved field radiotherapy (IF), including only the initially involved regions, showed no inferior outcome to WART. The IFRT definitions were based on two-dimensional radiation therapy planned without the use of modern imaging, on bony landmarks, and on anatomical regions defined using the Ann Arbor Staging Classification system. However, although IFRT represented a significant reduction in the volume irradiated compared to the previously used EFRT, it still involved treating relatively large volumes of normal tissue, even in patients in the early stages of the disease. Today, the extensive RT fields of the past are no longer needed and the current internationally recommended treatment concept for the irradiation of gastric MZL lymphoma is an involved site radiotherapy (ISRT) with 24-30 Gy over 3 to 4 weeks [27,34-36] (Figures 1 and 2; Table 1). Recent planning techniques attempt to further reduce the radiation dose in order to minimize the probability of normal tissue complication while maintaining tumor control [37]. 


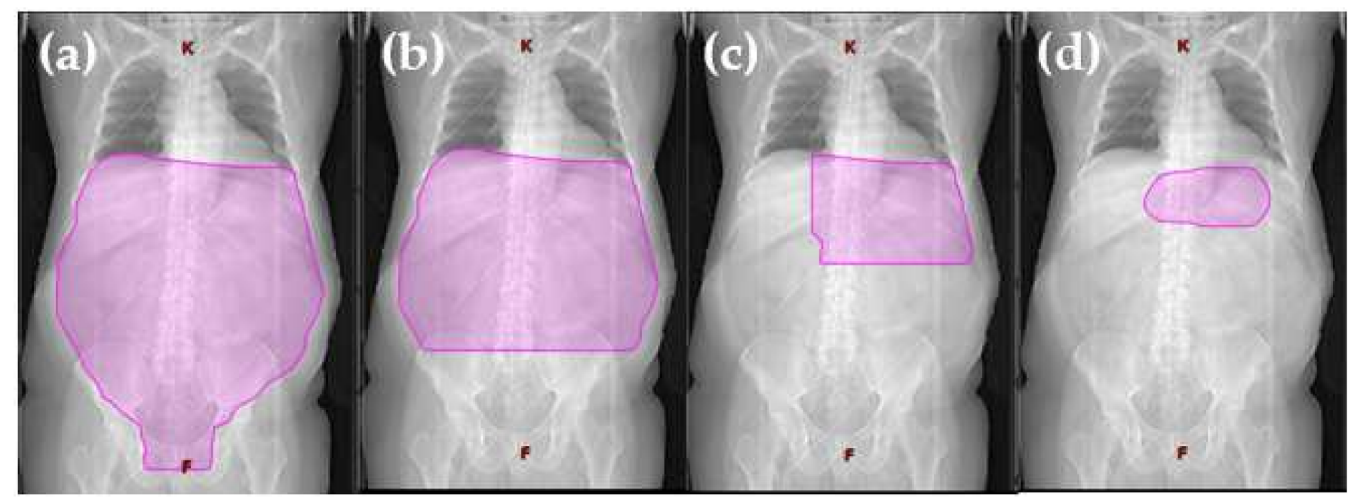

Figure 1. Visualization of radiation volume decrease from extended field to involved site radiotherapy. Definition of field sizes (a) Extended field (Burgers et al., 1988 [15]): the entire peritoneal cavity from the diaphragm to the pouch of Douglas and laterally to the side wall. (b) Reduced extended field (Willich et al., 2000 [38]): in the case of complete resection of a gastric tumor smaller than $5 \mathrm{~cm}$ in diameter, without submucosal perforation, the target volume was restricted to the upper and middle part of the abdomen, sparing the pelvis. (c) Involved field (Maor et al., 1990 [39]): the left upper quadrant (stomach, spleen, celiac, and paraaortic lymph nodes). (d) Involved site radiotherapy (ILROG guidelines Yahalom et al., 2015 [27]): the location is individualized to treat each patient's stomach and nearby lymph nodes, which can contain microscopic or macroscopic disease, in a highly conformal way using $3 \mathrm{D}$ imaging.

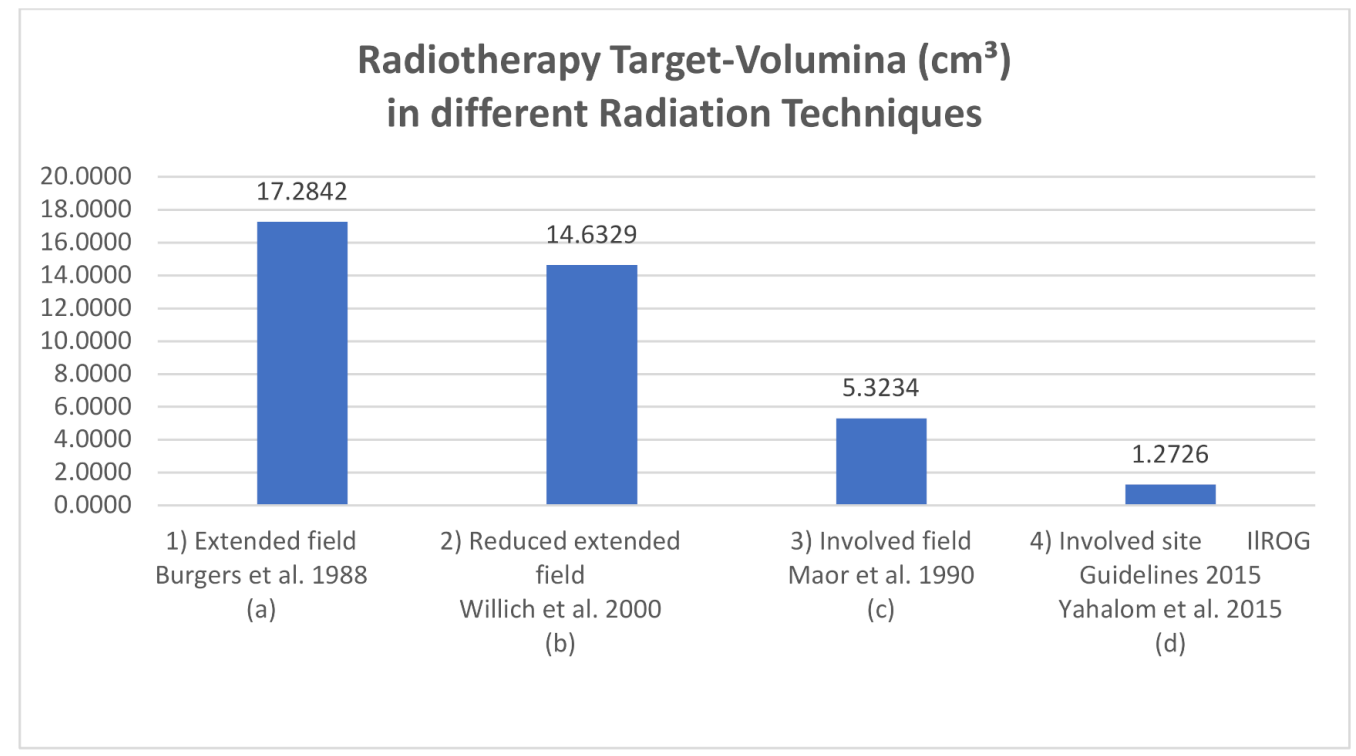

Figure 2. Exemplary RT-volume $\left(\mathrm{cm}^{3}\right)$ in different radiation techniques measured with a 3D-radiation planning program. Definition of field sizes (a) Extended field (Burgers et al., 1988 [15]): the entire peritoneal cavity from the diaphragm to the pouch of Douglas and laterally to the side wall. (b) Reduced extended field (Willich et al., 2000 [38]): in the case of complete resection of a gastric tumor smaller than $5 \mathrm{~cm}$ in diameter, without submucosal perforation, the target volume was restricted to the upper and middle part of the abdomen, sparing the pelvis. (c) Involved field (Maor et al., 1990 [39]): the left upper quadrant (stomach, spleen, celiac, and paraaortic lymph nodes). (d) Involved site radiotherapy (ILROG guidelines Yahalom et al., 2015 [27]): the location is individualized to treat each patient's stomach and nearby lymph nodes, which can contain microscopic or macroscopic disease, in a highly conformal way using 3D imaging. 
Table 1. The development of total radiation doses for the treatment of gMZL from the 1990s to the present day.

\begin{tabular}{|c|c|c|c|c|c|c|c|}
\hline $\begin{array}{c}\text { Publication } \\
\text { Author }\end{array}$ & $\begin{array}{c}\text { Publication } \\
\text { Year }\end{array}$ & References & $\begin{array}{l}\text { Study } \\
\text { Nature }\end{array}$ & $\begin{array}{l}\text { High Grade NHL } \\
\text { Included in N }\end{array}$ & $N$ & $\begin{array}{l}\text { Radiation } \\
\text { Dose (Gy) }\end{array}$ & $\begin{array}{c}\text { Single Dose } \\
\text { (Gy) }\end{array}$ \\
\hline Taal & 1993 & [40] & Retrospective & No & 42 & 40 & 2.0 \\
\hline Kocher & 1997 & [41] & Retrospective & No & 25 & $30-40$ & $1.5-2.0$ \\
\hline Schechter & 1998 & [42] & Retrospective & No & 17 & $\begin{array}{l}\text { median } 30 \\
(28.5-43.5)\end{array}$ & 1.5 \\
\hline Tsang & 2001 & [43] & Retrospective & No & 9 & $\begin{array}{l}\text { median } 25 \\
(20-30)\end{array}$ & $1.0-2.5$ \\
\hline Koch & 2001 & [14] & Prospective & Yes & 106 & 40 & $1.5-2.0$ \\
\hline Koch & 2005 & [44] & Prospective & No & 143 & 40 & $1.5-2.0$ \\
\hline Della Biancia & 2005 & [45] & Retrospective & No & 14 & 30 & Not available \\
\hline Avilés & 2005 & [46] & Prospective & No & 78 & 40 & Not available \\
\hline Watanabe & 2008 & [47] & Retrospective & No & 11 & 30 & 1.5 \\
\hline Vrieling & 2008 & [48] & Retrospective & No & 115 & 40 & $1.0-2.0$ \\
\hline Tomita & 2009 & [49] & Retrospective & No & 20 & $\begin{array}{c}\text { median } 32 \\
(25.6-50)\end{array}$ & $1.5-2.2$ \\
\hline Ono & 2010 & [50] & Retrospective & No & 8 & 30 & 1.5 \\
\hline Zullo & 2010 & [7] & Retrospective & No & 112 & $\begin{array}{l}\text { median } 30 \\
(22.5-43.5)\end{array}$ & $1.5-1.8$ \\
\hline Goda & 2010 & [51] & Retrospective & No & 25 & $\begin{array}{c}\text { median } 30 \\
(17.5-35)\end{array}$ & 2.5 \\
\hline Fischbach & 2011 & [52] & Prospective & No & 19 & 46 & $1.8-2.0$ \\
\hline Wirth & 2013 & [53] & Retrospective & No & 102 & $\begin{array}{c}\text { median } 40 \\
(26-46)\end{array}$ & median 1.8 \\
\hline Abe & 2013 & [54] & Retrospective & No & 34 & 30 & $1.5-2.0$ \\
\hline Teckie & 2015 & [29] & Retrospective & No & 123 & $\begin{array}{l}\text { median } 30 \\
\text { (Range } \\
\text { unknown) }\end{array}$ & 2.0 \\
\hline $\begin{array}{c}\text { Ruskone- } \\
\text { Fourmestraux }\end{array}$ & 2015 & [55] & Prospective & No & 232 & 30 & 2.0 \\
\hline Ohkubo & 2017 & [56] & Retrospective & No & 27 & $\begin{array}{l}\text { median } 30 \\
(30-39.5)\end{array}$ & 1.5 \\
\hline Pinnix & 2019 & [57] & Retrospective & No & 32 & $\begin{array}{c}\text { median } 30 \\
(24-36)\end{array}$ & 1.5 \\
\hline Reinartz & 2019 & [28] & Prospective & No & 290 & $\begin{array}{c}\text { median } 40 \\
(36-44)\end{array}$ & $1.8-2.0$ \\
\hline Yahalom & 2021 & [30] & Retrospective & No & 178 & $\begin{array}{l}\text { median } 30 \\
(22.5-43.5)\end{array}$ & 1.5 \\
\hline Saifi & 2021 & [58] & Retrospective & No & 42 & $\begin{array}{c}\text { median } 30 \\
(23.5-36)\end{array}$ & $1.5-2.0$ \\
\hline
\end{tabular}

This review discusses the development of indications for radiation therapy of gMZL, the dose of irradiation, the optimum treatment volume, and the related toxicity. [16]

\section{Extended Field Radiotherapy (EFRT)}

The treatment of gastric lymphoma with radiation therapy alone has been documented in the medical literature since the 1930s [59]. In 1939, Archer [59] reported on twenty gastric 
lymphosarcoma patients surviving 5 years after diagnosis. Eight patients were treated with biopsy and radiation alone, although this approach was commonly performed in patients with inoperable tumors.

Advances in technology enabled RT to treat large volumes, and extended field RT (EFRT), with prophylactic treatment of the entire abdomen, became the treatment of choice, thereby increasing disease-free survival (DFS) and overall survival (OS) rates [40,41,59-63]. Pathophysiologically, it was justified by dealing with the normal flow of the intraperitoneal fluid. Since the fluid reaches the pouch of Douglas and flows back up to the diaphragm, the gastrectomy would cause loose tumor cells to spread throughout the abdomen. The proliferation and dissemination of such cells can be prevented by whole abdominal radiotherapy (WART) [15]. Therefore, the radiation field encompassed the entire abdominal cavity in the longitudinal direction from the diaphragm to the pouch of Douglas and in transverse direction to the side wall, with dorsal shielding from the right kidney [15]. The boost covered the entire stomach, the paraaortic area to the level of L2-L3, depending on the location of the stomach, which was determined using barium meal pictures in the treatment position [21] (Figure 1a).

Most protocols used WART for primary or postoperative therapy of gastric lymphoma to a total dose of 20-30 Gy, with a sequential boost to the entire stomach bed and paraaortic node region of 40-45 Gy. Using EFRT, some studies demonstrated a survival advantage for postoperative radiation therapy [16,64-71]. Bush and Ash [66] found that WART at 25 Gy yielded a 2-year no evidence of disease survival (NED)rate of $64 \%$, and a 2 -year LC rate of $82 \%$, compared with $44 \%$ and $36 \%$ for patients treated with resection only, respectively. Herrmann [65] applied WART at 20 Gy, followed by a boost to the stomach bed and paraaortic lymph node region, noting an 80\% 5-year NED for patients solely treated with irradiation, $50 \%$ for patients solely resected, and $90 \%$ for patients with combined treatments. Similarly, Shiu [64] used WART at $25 \mathrm{~Gy}$ and boosted the gastric bed to $40 \mathrm{~Gy}$. The five-year survival rate was 33\% for patients solely resected, $67 \%$ for patients receiving postoperative irradiation, and $85 \%$ for those receiving more than $30 \mathrm{~Gy}$.

In 1988, Burgers et al. [15] reported on 24 stage I gastric NHL patients who were treated with irradiation alone. The RT consisted of a three-week WART treatment at 20 Gy, followed by an additional two-week treatment at $20 \mathrm{~Gy}$ with a boost at $40 \mathrm{~Gy}$. After a median follow-up of 48 months, the 4-year DFS was $83 \%$.

General prophylactic containment of the inguinal lymph nodes in the case of WART does not appear to be necessary [63].

When Fischbach [72] showed that the postoperatively irradiated patients had comparable chances of survival despite unfavorable selection criteria, such as incomplete resection, advanced stage, and other risk factors, a prospective study was carried out.

EFRT with boosts was used in the first prospective, multicenter study, GIT NHL 01/92, initiated at the University Hospital of Muenster, Germany [14,24,65]. Whether or not the treatment included surgery was at the discretion of each participating center. After resection, patients with low-grade or indolent histological subtypes of lymphoma in stages IE and IIE were treated with WART (30 Gy) and, in case of residual disease, an additional boost with $10 \mathrm{~Gy}$ was used. Without gastric resection, stage IE and IIE patients received EFRT (30 Gy + 10 Gy boost) using AP/PA opposing fields with individual shielding of the kidneys and of right lobe of the liver. There were no significant differences in survival rates between patients who were resected or solely irradiated as part of their treatment. From this point on, gastrectomy was no longer integrated into the standard therapy. Currently, in gMZL, surgical management is only necessary in the case of emergency indications, such as macroscopic bleeding or perforation.

\section{Reduced Extended Field Radiotherapy}

Shimm et al. showed that the size of the radiation fields can be reduced without affecting the prognosis in mixed gastric lymphoma. In their retrospective analysis, 19/26 patients with primary gastric lymphoma received postoperative radiation therapy. The AP-PA fields 
covered the gastric bed and the regional nodes (mean size, $323 \mathrm{~cm}^{2} ; 19 \mathrm{~cm} \times 17 \mathrm{~cm}$ ) (Figure 1). The mean dose was 36 Gy à 1.5-2.0 Gy and the 5-year OS was 58\%. Three patients who received postoperative radiation therapy had abdominal failures comparable to those receiving a previous series of WART radiation therapy [71].

In accordance, Lim found that after surgery, radiation treatment at 20-30 Gy of the gastric bed and para-aortic lymph nodes improved LC from $90 \%$ to $100 \%$ in mixed gastric lymphomas [73].

In the prospective multicenter study GIT NHL 02/96 of stage I and stage II primary GI lymphomas $[38,44]$, the aim was to de-escalate treatment. The radiation dose was $30 \mathrm{~Gy}$, followed by a $10 \mathrm{~Gy}$ boost to the tumor region if the resection was not complete. The radiotherapy volume of patients with indolent lymphoma stage I and microscopic (R1) or macroscopic (R2) residuals after gastric resection [74] included the upper and middle part of the abdomen. The lower field boundary was the fifth lumbar vertebra (as reduced extendedfield radiotherapy (red. EF), (30 Gy + 10 Gy boost to R1 or R2 regions), (Figure 1b). After complete resection, patients with stage II disease were treated with red. EF $30 \mathrm{~Gy}$, while after incomplete resection (R1 or R2), the target field was a WART with $30 \mathrm{~Gy}$, followed by a boost of $10 \mathrm{~Gy}$ to the gastric region. Non-resected patients were also treated with red. EF with 30 Gy in stage I and with WART 30 Gy in stage II. The tumor region was boosted with $10 \mathrm{~Gy}$. It should be emphasized that no disadvantage could be observed with the use of an organ-preserving treatment (OS at 42 month was $86 \%$ with surgery vs. $91 \%$ without surgery; the 5-year EFS was 70\%) [44]. In a prospective trial conducted by Avilés et al., 241 patients with early stage gMZL were randomized to receive surgery, radiotherapy, and chemotherapy. In the radiotherapy group, $30 \mathrm{~Gy}$ was administered using WART, with the liver and kidneys shielded. The upper abdomen treatment was boosted to $40 \mathrm{~Gy}$. EFS after 10 years was 52\% in the radiotherapy arm, 52\% with surgery, and $87 \%$ in the chemotherapy group. However, the overall survival rate showed no significant differences between the three groups [46].

\section{Involved Field Radiation Therapy (IFRT)}

Maor et al. reported on a series of 34 patients with stages IE and IIE gMZL who were treated with conservative treatment alone, consisting of chemotherapy in combination with involved field radiotherapy (IFRT). The chemotherapy consisted of cyclophosphamide, doxorubicin, vincristine, prednisone and bleomycin (CHOP-Bleo); or cyclophosphamide, methotrexate, etoposide, and dexamethasone (CMED). IFRT was started after four cycles of chemotherapy; the irradiation field included the left upper quadrant (stomach, spleen, celiac, and paraaortic lymph nodes), (Figure 1c). The total dose was 30 Gy to 50 Gy at $1.8 \mathrm{~Gy} /$ day. A dosage exceeding $40 \mathrm{~Gy}$ was delivered to a reduced field that addressed the lymphoma in the stomach. Additionally, up to eight cycles of chemotherapy were administered. The 5-year OS rate was $73 \%$ and the DFS rate was 62\% [39].

The successful treatment of gMZL with radiation alone at the Memorial Sloan Kettering Cancer Center was first announced in 1998 [42] and included 51 patients with H. pyloriindependent gMZL [10,42]. The patients received 30 Gy (28.5-43.5 Gy) in 1.5-Gy doses for a period of 4 weeks to the stomach and the local lymph nodes (low dose IFRT) using opposed anterior and posterior fields. An oral (2\%) barium sulfate suspension and inspiration and expiration radiographs were used to aid in localizing the stomach, and an intravenous pyelogram was used to locate the kidneys. To include the gastric lymph nodes in the treatment volume, a $2 \mathrm{~cm}$ margin around the gastric wall was added.

The 5-year freedom-from-treatment failure and the overall survival rates were $89 \%$ and $83 \%$, respectively. The cause-specific survival was $100 \%$.

In the German multicenter prospective trial DSGL 01/2003, RT was stratified according to the stage of disease, and stage IE was treated with IFRT and IIE with red. EF. In the area of the tumor, a dose of $40 \mathrm{~Gy}$ was applied and $30 \mathrm{~Gy}$ in case of the prophylactic extended area in the red. EF, using two-dimensional (2D) opposed radiation fields or three-dimensional (3D) conformal radiotherapy (CRT) [28] 
Overall, many authors have reported outstanding results after RT alone using IFRT and conventional 3D CRT [28,43,48,49,52,53,55,56,75].

\section{Involved Site Radiotherapy (ISRT)}

Modern advanced computed tomography (CT) imaging and highly conformal radiation therapy planning and delivery are currently used in patients with gMZL. Unlike most solid tumors, it is not necessary to irradiate the stomach with high doses of radiation, but rather to minimize the dose of radiation to normal tissues, as experience has shown that even relatively low doses cause significant long-term morbidity and mortality.

Current target volume and radiation dose guidelines for involved site RT (ISRT) are provided by the International Lymphoma Radiation Oncology Group (ILROG), a worldwide organization established in 2011 supporting the research on RT for lymphoma [27].

To date, no randomized trials comparing ISRT with IFRT have been published. It is unlikely that such studies will be conducted because, due to the low recurrence and side effect rates, a very high number of patients would have to be recruited in order to prove non-inferiority.

Rather than using the standard treatment fields of the past, ISRT is being individualized to treat each patient's stomach and nearby lymph nodes, which may contain microscopic or macroscopic disease, in a highly conformal way using 3D imaging (Figure 1d). The ISRT concept has been accepted as the standard for modern RT for gMZL by most centers and collaborative groups, including the National Comprehensive Cancer Network (NCCN) [76].

The clinical treatment volume (CTV) for gMZL includes the stomach and first part of the duodenum. Perigastric lymph nodes and other parts of the duodenum are also included in the clinical treatment volume if they are involved by disease. Using this target volume, the irradiated volume is significantly smaller than the volume used in the old IFRT technique [27] (Figure 1a-d).

Excellent outcome has been demonstrated with ISRT using pre-defined target volume (PTV) and 30 Gy for treatment planning [30,54,55,57,77]. The highest 5-year and 10-year overall survival rates reported to date were $94 \%$ and $79 \%$, respectively, comparable to the general population [22].

Intensity modulated radiation therapy (IMRT) with reduced dosage was used effectively in a recent series of 32 gMZL patients. The dose reduction to $24 \mathrm{~Gy}$ showed no disease failure 2 years after ISRT. The clinical target volume (CTV) for ISRT included the stomach alone for stage I or the stomach and involved lymph nodes for stage II, each with a safety margin of $2-3 \mathrm{~cm}[57]$.

\section{Toxicity of Radiotherapy Treatment}

The decrease in the size of the radiation fields (based on stage adaptations), along with advanced technological development, improved the ability to deliver treatment with less toxicity. Reinartz et al. assessed the toxicity of 290 patients with gMZL stage IE or IIE who were treated with radiotherapy between 1992 and 2013. Acute hemato- and gastrointestinal toxicity decreased significantly with the use of smaller radiation fields and modern radiation techniques. Chronic RT-associated side effects in organ functions were limited to a low grade and were rare [28], which is in agreement with other studies [13,30,51,53,78,79].

\subsection{Bleeding and Perforation}

For many decades, the major concern with radiation therapy and chemotherapy was the risk of fatal complications such as hemorrhage and perforation due to the malignant lesion or its therapy [80]. There are many warnings in the medical literature against treating gastric lymphoma without surgical resection, but this prevailing idea has not been confirmed in studies [68,70,81-84]. In 1990, Talamonti reported five patients with primary gastrointestinal lymphoma who initially received radiotherapy or chemotherapy 
and later developed severe tumor-related complications. However, all mentioned patients had advanced stage disease [85].

In contrast, in 1982, Mittal et al. showed that the frequency of perforations or bleeding due to radiotherapy is minimal. Only $1 \%(1 / 75)$ developed a gastric perforation directly associated with radiation therapy. Meanwhile, 10\% (3/29) died of surgical complications after gastrectomy. For the first time, adjuvant radiation was recommended for gastric lymphoma in stage IE and adjuvant radiation plus chemotherapy for stage IIE [23].

Consistent with these results, Varsos and Yahalom found that the incidence of perforation in the early stage of disease when treated with radiotherapy alone is below $5 \%$ (in contrast to an operative mortality rate of 0-22\%) [17], and in more recent studies, no bleeding or perforations occurred at all $[28,30]$.

\subsection{Renal Dysfunction}

The risk of renal impairment or hypertension due to the radiation therapy of gastric lymphoma patients is low. Maor et al. examined the renal function of 27 patients with stage I or II gastric lymphoma who received at least $24 \mathrm{~Gy}$ on $\geq 1 / 3$ of the left kidney with a median follow up at 3.4 years. Although shrinking of the ipsilateral kidney was detectable in most of the patients, only two patients developed mild hypertension. Urea or creatinine in serum was not elevated [86].

In WART, the right kidney should be shielded from behind [15], because if part or all of the right kidney receives a high dose of radiation, the risk of high blood pressure can increase [87].

The use of 4-field 3D CRT significantly reduces the radiation dose to the kidney. The addition of intensity modulated radiotherapy (IMRT) leads to further dose improvements for the left kidney and the liver in selected patients [45]. Using IMRT, the mean doses to the kidneys in standard dose ( $\geq 30 \mathrm{~Gy}$ ) and reduced dose ( $\leq 24 \mathrm{~Gy}$ ) radiotherapy can be $<5 \mathrm{~Gy}$, resulting in a minimal risk of renal impairment as a complication of radiotherapy [57].

In large trials, Reinartz [28] described grade 1-2 impaired chronic kidney function in only 3-7.9\% of 290 gMZL patients after RT, and Yahalom [30] and Wirth [53] did not observe any late renal failure.

\subsection{Heart Toxicity}

In the largest study on radiotherapy in gMZL, carried out by the German Study Group on Gastrointestinal Lymphoma (DSGL), 12 of 290 gMZL patients [28] treated with RT died of cardiovascular events, and in the study performed by the International Extranodal Lymphoma Study Group (IELSG), 8 of 102 gMZL patients treated with RT [53] died of cardiovascular events at a median follow-up of 6.4 years. However, in these studies, the effect of RT on cardiovascular risk remains uncertain. In Hodgkin's lymphoma and breast cancer, RT-associated heart toxicity has long been recognized, showing a linear radiation dose-response relationship [24,25]. Given the expected long-term survival rates, minimizing radiation exposure to the heart is indispensable for reducing the risk of late cardiac events for gMZL patients.

Due to the close proximity of the stomach to the base of the heart, motion management using the deep-inspiration breath-hold (DIBH) technique creates anatomical distance between the heart and the stomach and significantly reduces the dose of radiation to the heart [88]. Besides, modern radiation techniques and daily imaging also help to reduce the dose exposure to the heart. A Surveillance, Epidemiology, and End Results (SEER) database analysis of 2996 patients showed no increase in the risk of cardiac death among patients with stage I gMZL after radiotherapy [89].

\subsection{Secondary Malignancy}

Regardless of the type of lymphoma therapy used, the incidence of adenocarcinoma and precancerous lesions such as intestinal metaplasia (IM) after gastric lymphoma increases $[29,50,90-93]$. This relationship could be due to a common pathogenesis of gastric 
lymphoma, precancerous lesions, and adenocarcinoma as being a chronic H. pylori gastritis [93-96]. Another hypothesis is that the onset of IM on the gastric mucosa early after lymphoma regression could be due to destruction of the gastric glands by lymphoepithelial lesions, followed by immediate repair with intestinal cells [93]. Since the risk of gastric adenocarcinoma is described as six times higher in patients with gMZL, an accurate re-evaluation after diagnosis and treatment is warranted [5].

Although Au et al. [97] do not detect an increased incidence of secondary tumors in gMZL patients, patients with NHL are at a significantly elevated risk of secondary cancers for up to 20 years after diagnosis. The calculated risk of developing a second cancer after being diagnosed with NHL is $21 \%$ for the next 3-20 years, compared with the population-expected cumulative risk of $15 \%$ [32,33]. A larger radiation field or higher doses of radiation are important risk factors for the development of a secondary malignancy [98], and limiting these can reduce the rate of their occurrence. In agreement with this, the authors of the above-mentioned multicenter study analyzed 15 secondary malignancies discovered after WART in gMZL patients [53] and came to the conclusion that three pelvic malignancies in the entire abdomen cohort would likely have been avoided by using a limited radiation field.

\subsection{Motion Management and Daily Imaging}

Motion management using DIBH increases the distance between the base of the heart and the upper side of the stomach, leading to less radiation exposure of the heart $[26,27]$ and limiting breath-induced gastric movement, allowing for the use of smaller PTV margins. There can be considerable interfractional fluctuations in stomach volume, even with the use of long fasting periods. Daily Image-Guided RT (IGRT) improves target coverage, despite the use of low PTV margins $[57,99]$. With the addition of a breath-holding technique, the PTV margins could be reduced to 0.5 to $1.0 \mathrm{~cm}$ for the stomach, compared to the $1.5 \mathrm{~cm}$ margins when the patient is breathing freely $[57,79]$. Retrospective analysis of daily computed tomographic (CT) scans of gastric lymphoma patients showed that a margin of $1.5-2.5 \mathrm{~cm}$ is required for covering $95 \%$ of the stomach due to intra- and interfractional variations of the stomach position $[100,101]$. The greatest deviation of the gastric position has been documented intrafractionally in the superior-inferior direction and interfractionally in the lateral direction, requiring a margin up to $3.1 \mathrm{~cm}$ [47].

ILROG contouring guidelines recommended that the contouring of an internal target volume be determined by $4 \mathrm{D} \mathrm{CT}$ or by fluoroscopy to track the variation of stomach position [27]. When DIBH and daily volumetric imaging are not available, clinicians should consider the appropriate margins necessary to ensure consistent target coverage [27,102].

\section{Future Directions: Standard, Intermediate, or Ultra Low-Dose Radiotherapy?}

Because of the excellent outcomes of patients with gMZL after radiation treatment at $30 \mathrm{~Gy}$, dose de-escalation is under consideration. A randomized trial conducted in the United Kingdom suggests that $24 \mathrm{~Gy}$ is effective for low-grade B-cell lymphoma. However, in this study of 248 patients who received radiotherapy, only $17 \%$ had MZL, and the frequency of gMZL remains unclear [35].

Pinnix et al. reported on gMZL patients treated with 24 Gy low dose ISRT using IMRT and compared them to those treated with $\geq 30 \mathrm{~Gy}$ [57]. The patients who were treated with 24 Gy $(n=11)$ showed high rates of complete response. There was no correlation between the lower dose and local recurrence at a median follow-up of 55 months. In a recent retrospective study conducted by Saifi et al. of 42 patients with early stage gMZL, reduced dose RT using 23.5-27 Gy showed comparable efficacy to standard dose RT using 30-36 Gy [58].

The HELYX II [103] trial examined the outcomes of RT in patients with persistent lymphoma after H.pylori eradication or in H. pylori negative patients. Twenty-nine lowgrade gMZL lymphoma patients with stages IE and II1E lymphoma were randomized to acquire gastric RT at a dose of 25.2 or $36 \mathrm{~Gy}$ à $1.8 \mathrm{~Gy}$. Of the 29 randomized patients, 
22 patients completed the follow-up and could be analyzed after one year. No recurrences were found in either arm of the study at a median follow-up at 79 months [103].

In the International Extranodal Lymphoma Study Group (IELSG) multicenter study [53], the median total RT dose for gMZL was $40 \mathrm{~Gy}$; no patient received a dose <26 Gy. In line with Pinnix [57] and Schmelz [103], no association was found between radiation field size or dosage and treatment failure.

Taking advantage of the radiosensitivity of indolent lymphoma, 4 Gy may have efficacy in many cases. It is an alternative to the current standard radiation dose of $30 \mathrm{~Gy}$ in cases of palliation, re-irradiation, or if the longer duration of the treatment would prevent its completion [78,104-110].

Haas et al. reported on 109 indolent NHL patients with 304 symptomatic sites treated with $4 \mathrm{~Gy}$. The total response rate was $92 \%$, the $\mathrm{CR}$ rate was $61 \%$, and the median time to local progression was 42 months following the initial CR [110]. Other series using ultra-low dose radiotherapy in the treatment of NHL reported CR rates ranging from $37 \%$ to $84 \%$; however, the proportion of gMZL is unknown [106-109].

Ultra-low dose radiotherapy is delivered over only 2 days. Patients with a poor performance status or who are traveling from long distances can easily undergo this form of treatment. However, while $4 \mathrm{~Gy}$ can be effective in the palliative setting, local control is significantly inferior to $24 \mathrm{~Gy}$ (5-year local progression-free rate is $89.9 \%$ after $24 \mathrm{~Gy}$ and $70.4 \%$ after $4 \mathrm{~Gy}$ ), which remains the treatment schedule of choice for curative radiation therapy in MZL $[34,74,111]$.

At present, an open-label trial of the MD Anderson Cancer Center (ClinicalTrials.gov Identifier: NCT03680586, last accessed 31 January 2022) studies how well ultra-low dose radiation with $4 \mathrm{~Gy}$ works in treating patients with stage I-IV gMZL. If the response to $4 \mathrm{~Gy}$ is inadequate, higher-dose radiotherapy may be given at the discretion of the treating physician.

However, the biological mechanism of ultra-low dose radiotherapy is not fully understood. It activates many processes that lead to cell death and apoptosis, for example, it causes the inactivation of bcl-2 overexpression [112]. As a result p53, caspase-8 and -9 , might be overexpressed and macrophage activation might be upregulated [113]. The NCT03680586 study examines whether microbiome or micro-ribonucleic acid (RNA) profiles can predict the response to ultra-low dose radiation therapy. Another ongoing trial of the ILROG (ClinicalTrials.gov, Identifier: NCT04097067, last accessed 31 January 2022) assesses the correlation between blood serum biomarker levels and lymphoma response to radiation treatment.

With such potent biological effects within the cell, the rationale is that a dose greater than $4 \mathrm{~Gy}$, but lower than $24 \mathrm{~Gy}$, might be optimal. Hence, the open-label trial of the University Hospital of Muenster (ClinicalTrials.gov, Identifier: NCT04097067) in collaboration with the ILROG and the German Lymphoma Alliance (GLA), studies the effectiveness of intermediate low-dose radiation therapy with $10 \times 2$ Gy ISRT for the treatment of patients with indolent stage I-II stomach or duodenal lymphoma.

Low-dose radiotherapy and apoptosis-inducing drugs like rituximab may be an interesting combination for gMZL treatment. In vitro experiments show that rituximab can potentiate radiation-induced apoptosis in lymphoma cells, and it acts as a radiosensitizer $[114,115]$. Therefore, combination regimens could result in sound local control without losing the benefits of systemic effects [116].

\section{Conclusions}

This review emphasizes the historically changing role of radiation therapy for gMZL, examining gastrectomy as the previously accepted treatment of choice to the current use of definitive low dose RT alone. It exemplifies the dramatic changes in radiation therapy from high-dose, large-field techniques to low-dose, localized target volumes based on advanced imaging, three-dimensional treatment planning, and advanced treatment delivery techniques, reducing toxicity while maintaining efficacy. 
This review provides compelling evidence supporting the continued use of RT as a safe and highly effective therapy for gMZL. Acute or late therapy-related toxicities are very rare, demonstrating the safety of this treatment.

The ISRT concept for gMZL, as defined by the ILROG, individualizes the treatment of each patient's stomach and nearby lymph nodes in a highly conformed way, using modern imaging for treatment planning and delivery. This treatment has been accepted as the standard for modern RT. With the reduction of the target volume in ISRT, the irradiation of normal tissue is significantly reduced compared to the more extensive treatment fields of the past, which leads to a reduction in the risk of long-term complications.

The evidence so far confirms these expectations, but the concept was only recently introduced. Longer periods of follow-up with careful analysis of the incidence of recurrence and the risk of long-term complications is required to assess the full effect of the ISRT concept and reduced doses in RT for gMZL.

Author Contributions: Conceptualization, H.T.E. and G.R.; methodology, G.R. and D.R.; software, S.R. and C.K.; validation, D.R., G.R., S.R., C.K. and H.T.E.; formal analysis, S.R. and C.K.; investigation, D.R.; resources, G.R. and D.R.; data curation, S.R., C.K. and H.T.E.; writing-original draft preparation, D.R. and G.R.; writing-review and editing, D.R., G.R., S.R., C.K. and H.T.E.; visualization, D.R. and G.R.; supervision, H.T.E.; project administration, G.R. and H.T.E.; funding acquisition, G.R. and H.T.E. All authors have read and agreed to the published version of the manuscript.

Funding: This research received no external funding. The authors acknowledge support from the Open Access Publication Fund of the University of Muenster.

Acknowledgments: We gratefully acknowledge the support and funding from the Interdisciplinary Center for Clinical Research (IZKF) in Muenster, Germany, and from the German Leukemia and Lymphoma Aid (DLH) in Bonn, Germany.

Conflicts of Interest: The authors declare no conflict of interest.

\section{References}

1. Zucca, E.; Bergman, C.C.; Ricardi, U.; Thieblemont, C.; Raderer, M.; Ladetto, M. Gastric marginal zone lymphoma of MALT type: ESMO Clinical Practice Guidelines for diagnosis, treatment and follow-up. Ann. Oncol. 2013, 24, vi144-vi148. [CrossRef] [PubMed]

2. Isaacson, P.; Wright, D.H. Extranodal malignant lymphoma arising from mucosa-associated lymphoid tissue. Cancer 1984, 53, 2515-2524. [CrossRef]

3. Wotherspoon, A.; Diss, T.; Pan, L.; Isaacson, P.; Doglioni, C.; Moschini, A.; De Boni, M. Regression of primary low-grade B-cell gastric lymphoma of mucosa-associated lymphoid tissue type after eradication of Helicobacter pylori. Lancet 1993, 342, 575-577. [CrossRef]

4. Severson, R.K.; Davis, S. Increasing incidence of primary gastric lymphoma. Cancer 1990, 66, 1283-1287. [CrossRef]

5. Capelle, L.; de Vries, A.; Looman, C.; Casparie, M.; Boot, H.; Meijer, G.; Kuipers, E. Gastric MALT lymphoma: Epidemiology and high adenocarcinoma risk in a nation-wide study. Eur. J. Cancer 2008, 44, 2470-2476. [CrossRef]

6. Dreyling, M.; Thieblemont, C.; Gallamini, A.; Arcaini, L.; Campo, E.; Hermine, O.; Kluin-Nelemans, J.C.; Ladetto, M.; Le Gouill, S.; Iannitto, E.; et al. ESMO Consensus conferences: Guidelines on malignant lymphoma. Part 2: Marginal zone lymphoma, mantle cell lymphoma, peripheral T-cell lymphoma. Ann. Oncol. 2013, 24, 857-877. [CrossRef]

7. Zullo, A.; Hassan, C.; Cristofari, F.; Andriani, A.; De Francesco, V.; Ierardi, E.; Tomao, S.; Stolte, M.; Morini, S.; Vaira, D. Effects of Helicobacter pylori Eradication on Early Stage Gastric Mucosa-Associated Lymphoid Tissue Lymphoma. Clin. Gastroenterol. Hepatol. 2010, 8, 105-110. [CrossRef]

8. Stathis, A.; Chini, C.; Bertoni, F.; Proserpio, I.; Capella, C.; Mazzucchelli, L.; Pedrinis, E.; Cavalli, F.; Pinotti, G.; Zucca, E. Long-term outcome following Helicobacter pylori eradication in a retrospective study of 105 patients with localized gastric marginal zone B-cell lymphoma of MALT type. Ann. Oncol. 2009, 20, 1086-1093. [CrossRef]

9. Ruskone-Fourmestraux, A.; Fischbach, W.; Aleman, B.M.P.; Boot, H.; Du, M.Q.; Megraud, F.; Montalban, C.; Raderer, M.; Savio, A.; Wotherspoon, A.; et al. EGILS consensus report. Gastric extranodal marginal zone B-cell lymphoma of MALT. Gut 2011, 60, 747-758. [CrossRef]

10. Schechter, N.R.; Yahalom, J. Low-grade MALT lymphoma of the stomach: A review of treatment options. Int. J. Radiat. Oncol. 2000, 46, 1093-1103. [CrossRef] 
11. Fischbach, W.; Goebeler, M.E.; Ruskone-Fourmestraux, A.; Wundisch, T.; Neubauer, A.; Raderer, M.; Savio, A.; EGILS (European Gastro-Intestinal Lymphoma Study) Group. Most patients with minimal histological residuals of gastric MALT lymphoma after successful eradication of Helicobacter pylori can be managed safely by a watch and wait strategy: Experience from a large international series. Gut 2007, 56, 1685-1687. [CrossRef]

12. Ducreux, M.; Boutron, M.; Piard, F.; Carli, P.; Faivre, J. A 15-year series of gastrointestinal non-Hodgkin's lymphomas: A population-based study. Br. J. Cancer 1998, 77, 511-514. [CrossRef]

13. Yoon, S.S.; Coit, D.G.; Portlock, C.S.; Karpeh, M.S. The Diminishing Role of Surgery in the Treatment of Gastric Lymphoma. Ann. Surg. 2004, 240, 28-37. [CrossRef]

14. Koch, P.; Del Valle, F.; Berdel, W.E.; Willich, N.A.; Reers, B.; Hiddemann, W.; Grothaus-Pinke, B.; Reinartz, G.; Brockmann, J.; Temmesfeld, A.; et al. Primary Gastrointestinal Non-Hodgkin's Lymphoma: II. Combined Surgical and Conservative or Conservative Management Only in Localized Gastric Lymphoma-Results of the Prospective German Multicenter Study GIT NHL 01/92. J. Clin. Oncol. 2001, 19, 3874-3883. [CrossRef]

15. Burgers, J.; Taal, B.; Van Heerde, P.; Somers, R.; Jager, F.H.; Hart, A. Treatment results of primary stage I and II non-Hodgkin's lymphoma of the stomach. Radiother. Oncol. 1988, 11, 319-325. [CrossRef]

16. Mittal, B.; Wasserman, T.H.; Griffith, R.C. Non-Hodgkin's lymphoma of the stomach. Am. J. Gastroenterol. 1983, 78, 780-787.

17. Varsos, G.; Yahalom, J. Alternatives in the Management of Gastric Lymphoma. Leuk. Lymphoma 1991, 4, 1-8. [CrossRef]

18. Morton, J.; Leyland, M.; Hudson, G.V.; Anderson, L.; Bennett, M.; MacLennan, K.; Hudson, B.V. Primary gastrointestinal non-Hodgkin's lymphoma: A review of 175 British National Lymphoma Investigation cases. Br. J. Cancer 1993, 67, 776-782. [CrossRef]

19. Ruskoné-Fourmestraux, A.; Aegerter, P.; Delmer, A.; Brousse, N.; Galian, A.; Rambaud, J.-C. Primary digestive tract lymphoma: A prospective multicentric study of 91 patients. Gastroenterology 1993, 105, 1662-1671. [CrossRef]

20. Amer, M.H.; El-Akkad, S. Gastrointestinal lymphoma in adults: Clinical features and management of 300 cases. Gastroenterology 1994, 106, 846-858. [CrossRef]

21. Sonnen, R.; Calavrezos, A.; Grimm, H.A.; Kuse, R. Kombinierte konservative Behandlung von lokalisierten Magenlymphomen DMW-Dtsch. Med. Wochenschr. 1994, 119, 863-868. [CrossRef]

22. Brincker, H.; D'Amore, F. A Retrospective Analysis of Treatment Outcome in 106 Cases of Localized Gastric Non-Hodgkin Lymphomas. Leuk. Lymphoma 1995, 18, 281-288. [CrossRef]

23. Liang, R.; Todd, D.; Chan, T.K.; Chiu, E.; Lie, A.; Kwong, Y.-L.; Choy, D.; Ho, F.C.S. Prognostic factors for primary gastrointestinal lymphoma. Hematol. Oncol. 1995, 13, 153-163. [CrossRef]

24. Koch, P.; Del Valle, F.; Berdel, W.E.; Willich, N.A.; Reers, B.; Hiddemann, W.; Grothaus-Pinke, B.; Reinartz, G.; Brockmann, J.; Temmesfeld, A.; et al. Primary Gastrointestinal Non-Hodgkin's Lymphoma: I. Anatomic and Histologic Distribution, Clinical Features, and Survival Data of 371 Patients Registered in the German Multicenter Study GIT NHL 01/92. J. Clin. Oncol. 2001, 19, 3861-3873. [CrossRef]

25. Specht, L. The history of radiation therapy of lymphomas and description of early trials. In On-Hodgkin's Lymphomas, 2nd ed.; Armitage, J.O., Coiffier, B., Dalla-Favera, R., Harris, N., Mauch, P.M., Eds.; Lippincott Williams \& Wilkins: Baltimore, MD, USA, 2009; pp. 12-24.

26. Zucca, E.; Bertoni, F.; Roggero, E.; Bosshard, G.; Cazzaniga, G.; Pedrinis, E.; Biondi, A.; Cavalli, F. Molecular Analysis of the Progression fromHelicobacter pylori-Associated Chronic Gastritis to Mucosa-Associated Lymphoid-Tissue Lymphoma of the Stomach. N. Engl. J. Med. 1998, 338, 804-810. [CrossRef]

27. Yahalom, J.; Illidge, T.; Specht, L.; Hoppe, R.T.; Li, Y.-X.; Tsang, R.; Wirth, A. Modern Radiation Therapy for Extranodal Lymphomas: Field and Dose Guidelines from the International Lymphoma Radiation Oncology Group. Int. J. Radiat. Oncol. 2015, 92, 11-31. [CrossRef]

28. Reinartz, G.; Pyra, R.P.; Lenz, G.; Liersch, R.; Stüben, G.; Micke, O.; Willborn, K.; Hess, C.F.; Probst, A.; Fietkau, R.; et al Erfolgreiche Strahlenfeldverkleinerung bei gastralem Marginalzonenlymphom: Erfahrungen der Deutschen Studiengruppe Gastrointestinale Lymphome (DSGL). Strahlenther. Onkol. 2019, 195, 544-557. [CrossRef]

29. Teckie, S.; Qi, S.; Lovie, S.; Navarrett, S.; Hsu, M.; Noy, A.; Portlock, C.; Yahalom, J. Long-Term Outcomes and Patterns of Relapse of Early-Stage Extranodal Marginal Zone Lymphoma Treated with Radiation Therapy with Curative Intent. Int. J. Radiat. Oncol. 2015, 92, 130-137. [CrossRef]

30. Yahalom, J.; Xu, A.J.; Noy, A.; Lobaugh, S.; Chelius, M.; Chau, K.; Portlock, C.; Hajj, C.; Imber, B.S.; Straus, D.J.; et al. Involved-site radiotherapy for Helicobacter pylori-independent gastric MALT lymphoma: 26 years of experience with 178 patients. Blood Adv. 2021, 5, 1830-1836. [CrossRef]

31. Loehr, W.J.; Mujahed, Z.; Zahn, F.D.; Gray, G.F.; Thorbjarnarson, B. Primary Lymphoma of the Gastrointestinal Tract. Ann. Surg. 1969, 170, 232-238. [CrossRef]

32. Travis, L.B.; Curtis, R.E.; Glimelius, B.; Holowaty, E.; Leeuwen, F.E.V.; Lynch, C.F.; Adami, J.; Gospodarowicz, M.; Wacholder, S.; Inskip, P.; et al. Second Cancers Among Long-term Survivors of Non-Hodgkin's Lymphoma. JNCI J. Natl. Cancer Inst. 1993, 85, 1932-1937. [CrossRef] [PubMed]

33. Travis, L.B.; Ng, A.K.; Allan, J.; Pui, C.-H.; Kennedy, A.R.; Xu, X.G.; Purdy, J.A.; Applegate, K.; Yahalom, J.; Constine, L.S.; et al. Second Malignant Neoplasms and Cardiovascular Disease Following Radiotherapy. JNCI J. Natl. Cancer Inst. 2012, 104, 357-370. [CrossRef] [PubMed] 
34. Hoskin, P.J.; Kirkwood, A.A.; Popova, B.; Smith, P.; Robinson, M.; Gallop-Evans, E.; Coltart, S.; Illidge, T.; Madhavan, K.; Brammer, C.; et al. 4 Gy versus 24 Gy radiotherapy for patients with indolent lymphoma (FORT): A randomised phase 3 non-inferiority trial. Lancet Oncol. 2014, 15, 457-463. [CrossRef]

35. Lowry, L.; Smith, P.; Qian, W.; Falk, S.; Benstead, K.; Illidge, T.; Linch, D.; Robinson, M.; Jack, A.; Hoskin, P. Reduced dose radiotherapy for local control in non-Hodgkin lymphoma: A randomised phase III trial. Radiother. Oncol. 2011, 100, 86-92. [CrossRef]

36. Zelenetz, A.D.; Gordon, L.I.; Abramson, J.S.; Advani, R.H.; Bartlett, N.; Caimi, P.F.; Chang, J.E.; Chavez, J.C.; Christian, B.; Fayad, L.E.; et al. NCCN Guidelines Insights: B-Cell Lymphomas, Version 3.2019. J. Natl. Compr. Cancer Netw. 2019, 17, 650-661. [CrossRef]

37. Reinartz, G.; Baehr, A.; Kittel, C.; Oertel, M.; Haverkamp, U.; Eich, H. Biophysical Analysis of Acute and Late Toxicity of Radiotherapy in Gastric Marginal Zone Lymphoma-Impact of Radiation Dose and Planning Target Volume. Cancers 2021, 13, 1390. [CrossRef]

38. Willich, N.A.; Reinartz, G.; Horst, E.J.; Delker, G.; Reers, B.; Hiddemann, W.; Tiemann, M.; Parwaresch, R.; Grothaus-Pinke, B.; Kocik, J.; et al. Operative and conservative management of primary gastric lymphoma: Interim results of a German multicenter study. Int. J. Radiat. Oncol. 2000, 46, 895-901. [CrossRef]

39. Maor, M.H.; Velasquez, W.S.; Fuller, L.M.; Silvermintz, K.B. Stomach conservation in stages IE and IIE gastric non-Hodgkin's lymphoma. J. Clin. Oncol. 1990, 8, 266-271. [CrossRef]

40. Taal, B.G.; Burgers, J.M.; van Heerde, P.; Hart, A.A.; Somers, R. The clinical spectrum and treatment of primary non-Hodgkin's lymphoma of the stomach. Ann. Oncol. 1993, 4, 839-846. [CrossRef]

41. Kocher, M.; Müller, R.-P.; Ross, D.; Hoederath, A.; Sack, H. Radiotherapy for treatment of localized gastrointestinal non-Hodgkin's lymphoma. Radiother. Oncol. 1997, 42, 37-41. [CrossRef]

42. Schechter, N.R.; Portlock, C.S.; Yahalom, J. Treatment of mucosa-associated lymphoid tissue lymphoma of the stomach with radiation alone. J. Clin. Oncol. 1998, 16, 1916-1921. [CrossRef]

43. Tsang, R.W.; Gospodarowicz, M.K. Management of localized (stage I and II) clinically aggressive lymphomas. Ann. Hematol. 2001, 80, B66-B72. [CrossRef]

44. Koch, P.; Probst, A.; Berdel, W.E.; Willich, N.A.; Reinartz, G.; Brockmann, J.; Liersch, R.; Del Valle, F.; Clasen, H.; Hirt, C.; et al. Treatment Results in Localized Primary Gastric Lymphoma: Data of Patients Registered within the German Multicenter Study (GIT NHL 02/96). J. Clin. Oncol. 2005, 23, 7050-7059. [CrossRef]

45. Della Biancia, C.; Hunt, M.; Furhang, E.; Wu, E.; Yahalom, J. Radiation treatment planning techniques for lymphoma of the stomach. Int. J. Radiat. Oncol. 2005, 62, 745-751. [CrossRef]

46. Avilés, A.; Nambo, M.J.; Neri, N.; Talavera, A.; Cleto, S. Mucosa-associated lymphoid tissue (MALT) lymphoma of the stomach Results of a controlled clinical trial. Med. Oncol. 2005, 22, 57-62. [CrossRef]

47. Watanabe, M.; Isobe, K.; Uno, T.; Harada, R.; Kobayashi, H.; Ueno, N.; Ito, H. Intrafractional gastric motion and interfractional stomach deformity using CT images. J. Radiat. Res. 2011, 52, 660-665. [CrossRef]

48. Vrieling, C.; de Jong, D.; Boot, H.; de Boer, J.P.; Wegman, F.; Aleman, B.M.P. Long-term results of stomach-conserving therapy in gastric MALT lymphoma. Radiother. Oncol. 2008, 87, 405-411. [CrossRef]

49. Tomita, N.; Kodaira, T.; Tachibana, H.; Nakamura, T.; Mizoguchi, N.; Takada, A. Favorable outcomes of radiotherapy for early-stage mucosa-associated lymphoid tissue lymphoma. Radiother. Oncol. 2009, 90, 231-235. [CrossRef]

50. Ono, S.; Kato, M.; Takagi, K.; Kodaira, J.; Kubota, K.; Matsuno, Y.; Komatsu, Y.; Asaka, M. Long-term treatment of localized gastric marginal zone B-cell mucosa associated lymphoid tissue lymphoma including incidence of metachronous gastric cancer. $J$. Gastroenterol. Hepatol. 2010, 25, 804-809. [CrossRef]

51. Goda, J.S.; Gospodarowicz, M.; Pintilie, M.; Wells, W.; Hodgson, D.C.; Sun, A.; Crump, M.; Tsang, R.W. Long-term outcome in localized extranodal mucosa-associated lymphoid tissue lymphomas treated with radiotherapy. Cancer 2010, 116, 3815-3824. [CrossRef]

52. Fischbach, W.; Schramm, S.; Goebeler, E. Outcome and quality of life favour a conservative treatment of patients with primary gastric lymphoma. Z. Gastroenterol. 2011, 49, 430-435. [CrossRef] [PubMed]

53. Wirth, A.; Gospodarowicz, M.; Aleman, B.M.P.; Bressel, M.; Ng, A.; Chao, M.; Hoppe, R.T.; Thieblemont, C.; Tsang, R.; Moser, L.; et al. Long-term outcome for gastric marginal zone lymphoma treated with radiotherapy: A retrospective, multi-centre, International Extranodal Lymphoma Study Group study. Ann. Oncol. 2013, 24, 1344-1351. [CrossRef] [PubMed]

54. Abe, S.; Oda, I.; Inaba, K.; Suzuki, H.; Yoshinaga, S.; Nonaka, S.; Morota, M.; Murakami, N.; Itami, J.; Kobayashi, Y.; et al. A Retrospective Study of 5-year Outcomes of Radiotherapy for Gastric Mucosa-associated Lymphoid Tissue Lymphoma Refractory to Helicobacter pylori Eradication Therapy. Jpn. J. Clin. Oncol. 2013, 43, 917-922. [CrossRef] [PubMed]

55. Ruskoné-Fourmestraux, A.; Matysiak-Budnik, T.; Fabiani, B.; Cervera, P.; Brixi, H.; Le Malicot, K.; Nion-Larmurier, I.; Fléjou, J.-F.; Hennequin, C.; Quéro, L. Exclusive moderate-dose radiotherapy in gastric marginal zone B-cell MALT lymphoma: Results of a prospective study with a long term follow-up. Radiother. Oncol. 2015, 117, 178-182. [CrossRef]

56. Ohkubo, Y.; Saito, Y.; Ushijima, H.; Onishi, M.; Kazumoto, T.; Saitoh, J.-I.; Kubota, N.; Kobayashi, H.; Maseki, N.; Nishimura, Y.; et al. Radiotherapy for localized gastric mucosa-associated lymphoid tissue lymphoma: Long-term outcomes over 10 years. J. Radiat. Res. 2017, 58, 537-542. [CrossRef] 
57. Pinnix, C.C.; Gunther, J.R.; Milgrom, S.A.; Cruz-Chamorro, R.; Medeiros, L.J.; Khoury, J.D.; Amini, B.; Neelapu, S.; Lee, H.J.; Westin, J.; et al. Outcomes After Reduced-Dose Intensity Modulated Radiation Therapy for Gastric Mucosa-Associated Lymphoid Tissue (MALT) Lymphoma. Int. J. Radiat. Oncol. 2019, 104, 447-455. [CrossRef]

58. Saifi, O.; Lester, S.C.; Rule, W.; Stish, B.J.; Stafford, S.; Pafundi, D.H.; Jiang, L.; Menke, D.; Moustafa, M.A.; Rosenthal, A.; et al. Comparable Efficacy of Reduced Dose Radiation Therapy for the Treatment of Early Stage Gastric Extranodal Marginal Zone Lymphoma of Mucosa-Associated Lymphoid Tissue. Adv. Radiat. Oncol. 2021, 6, 100714. [CrossRef]

59. Archer, V.W.; Cooper, G. Lymphosarcoma of the stomach, diagnosis and treatment. Am. J. Roentgenol. 1939, 42, 332-340.

60. Musshoff, K.; Schmidt-Vollmer, H. Prognostic significance of primary site after radiotherapy in non-Hodgkin's lymphomata. Br. J. Cancer Suppl. 1975, 2, 425-434.

61. Rosenberg, S.A.; Dorfman, R.F.; Kaplan, H.S. A summary of the results of a review of 405 patients with non-Hodgkin's lymphoma at Stanford University. Br. J. Cancer Suppl. 1975, 2, 168-173.

62. Sutcliffe, S.B.; Gospodarowicz, M.K.; Bush, R.S.; Brown, T.C.; Chua, T.; Bean, H.A.; Clark, R.M.; Dembo, A.; Fitzpatrick, P.J.; Peters, M.V. Role of radiation therapy in localized non-Hodgkin's lymphoma. Radiother. Oncol. 1985, 4, 211-223. [CrossRef]

63. Reinartz, G.; Kardels, B.; Koch, P.; Willich, N. Analysis of Failures after Whole Abdominal Irradiation in Gastrointestinal Lympomas. Is Prophylactic Irradiation of Inguinal Lymph Nodes Required? German Multicenter Study Group on GI-NHL, University of Muenster. Strahlenther. Onkol. 1999, 175, 601-605. [CrossRef]

64. Shiu, M.H.; Karas, M.; Nisce, L.; Lee, B.J.; Filippa, D.A.; Lieberman, P.H. Management of Primary Gastric Lymphoma. Ann. Surg. 1982, 195, 196-202. [CrossRef]

65. Herrmann, R.; Panahon, A.M.; Barcos, M.P.; Walsh, D.; Stutzman, L. Gastrointestinal involvement in non-Hodgkin's lymphoma Cancer 1980, 46, 215-222. [CrossRef]

66. Bush, R.S.; Ash, C.L. Primary Lymphoma of the Gastrointestinal Tract. Radiology 1969, 92, 1349-1354. [CrossRef]

67. Hockey, M.S.; Powell, J.; Crocker, J.; Fielding, J.W.L. Primary gastric lymphoma. Br. J. Surg. 1987, 74, 483-487. [CrossRef]

68. Jones, R.E.; Willis, S.; Innes, D.J.; Wanebo, H.J. Primary gastric lymphoma: Problems in staging and management. Am. J. Surg. 1988, 155, 118-123. [CrossRef]

69. Contreary, K.; Nance, F.C.; Becker, W.F. Primary Lymphoma of the Gastrointestinal Tract. Ann. Surg. 1980, 191, 593-598. [CrossRef]

70. Rosen, C.B.; VAN Heerden, J.A.; Martin, J.K.; Wold, L.E.; Ilstrup, D.M. Is an Aggressive Surgical Approach to the Patient with Gastric Lymphoma Warranted? Ann. Surg. 1987, 205, 634-640. [CrossRef]

71. Shimm, D.S.; Dosoretz, D.E.; Anderson, T.; Linggood, R.M.; Harris, N.L.; Wang, C.C. Primary gastric lymphoma. An analysis with emphasis on prognostic factors and radiation therapy. Cancer 1983, 52, 2044-2048. [CrossRef]

72. Fischbach, W.; Dragosics, B.; Kolve-Goebeler, M.; Ohmann, C.; Greiner, A.; Yang, Q.; Böhm, S.; Verreet, P.; Horstmann, O.; Busch, M.; et al. Primary gastric B-Cell lymphoma: Results of a prospective multicenter study. Gastroenterology 2000, 119, 1191-1202. [CrossRef]

73. Lim, F.E.; Hartman, A.S.; Tan, E.G.C.; Cady, B.; Meissner, W.A. Factors in the prognosis of gastric lymphoma. Cancer 1977, 39, 1715-1720. [CrossRef]

74. Hoskin, P.; Popova, B.; Schofield, O.; Brammer, C.; Robinson, M.; Brunt, A.M.; Madhavan, K.; Illidge, T.; Gallop-Evans, E.; Syndikus, I.; et al. 4 Gy versus 24 Gy radiotherapy for follicular and marginal zone lymphoma (FoRT): Long-term follow-up of a multicentre, randomised, phase 3, non-inferiority trial. Lancet Oncol. 2021, 22, 332-340. [CrossRef]

75. Tsang, R.W.; Gospodarowicz, M.K.; Pintilie, M.; Wells, W.; Hodgson, D.C.; Sun, A.; Crump, M.; Patterson, B.J. Localized MucosaAssociated Lymphoid Tissue Lymphoma Treated with Radiation Therapy Has Excellent Clinical Outcome. J. Clin. Oncol. 2003, 21, 4157-4164. [CrossRef]

76. Zelenetz, A.D.; Gordon, L.I.; Chang, J.E.; Christian, B.; Abramson, J.S.; Advani, R.H.; Bartlett, N.L.; Budde, L.E.; Caimi, P.F.; De Vos, S. NCCN Clinical Practice Guidelines in Oncology: Non-Hodgkin's Lymphomas. NCCN Guidelines Insights: B-Cell Lymphomas, Version 5.2021. J. Natl. Compr. Cancer Netw. 2021, 19, 1218-1230. [CrossRef]

77. Pinnix, C.C.; Dabaja, B.S.; Milgrom, S.A.; Smith, G.L.; Abou, Z.; Nastoupil, L.; Romaguera, J.; Turturro, F.; Fowler, N.; Fayad, L.; et al. Ultra-low-dose radiotherapy for definitive management of ocular adnexal B-cell lymphoma. Head Neck 2017, 39, 1095-1100. [CrossRef]

78. Wang, Y.-G.; Zhao, L.-Y.; Liu, C.-Q.; Pan, S.-C.; Chen, X.-L.; Liu, K.; Zhang, W.-H.; Yang, K.; Chen, X.-Z.; Zhang, B.; et al. Clinical characteristics and prognostic factors of primary gastric lymphoma: A retrospective study with 165 cases. Medicine 2016, 95, e4250. [CrossRef]

79. Kim, S.-W. Clinical outcomes of radiation therapy for early-stage gastric mucosa-associated lymphoid tissue lymphoma. World J. Gastroenterol. 2013, 19, 6062-6068. [CrossRef] [PubMed]

80. Fleming, I.D.; Mitchell, S.; Dilawari, R.A. The role of surgery in the management of gastric lymphoma. Cancer 1982, 49, 1135-1141 [CrossRef]

81. Taylor, E.S. Primary lymphosarcoma of the stomach. Ann. Surg. 1939, 110, 200-221. [CrossRef] [PubMed]

82. Hande, K.R.; Fisher, R.I.; Devita, V.T.; Chabner, B.A.; Young, R.C. Diffuse histiocytic lymphoma involving the gas-trointestinal tract. Cancer 1978, 41, 1984-1989. [CrossRef]

83. Steward, W.; Harris, M.; Wagstaff, J.; Scarffe, J.; Deakin, D.; Todd, I.; Crowther, D. A prospective study of the treatment of high-grade histology non-Hodgkin's lymphoma involving the gastrointestinal tract. Eur. J. Cancer Clin. Oncol. 1985, 21, 1195-1200. [CrossRef] 
84. Rosenfelt, F.; Rosenberg, S.A. Diffuse histiocytic lymphoma presenting with gastrointestinal tract lesions the stan-ford experience. Cancer 1980, 45, 2188-2193. [CrossRef]

85. Talamonti, M.S.; Dawes, L.G.; Joehl, R.J.; Nahrwold, D.L. Gastrointestinal Lymphoma: A case for primary surgical resection. Arch Surg. 1990, 125, 972-977. [CrossRef]

86. Maor, M.H.; North, L.B.; Cabanillas, F.F.; Ames, A.L.; Hess, M.A.; Cox, J.D. Outcomes of high-dose unilateral kidney irradiation in patients with gastric lymphoma. Int. J. Radiat. Oncol. 1998, 41, 647-650. [CrossRef]

87. Verheij, M.; Dewit, L.G.; Olmos, R.A.V.; Arisz, L. Evidence for a renovascular component in hypertensive patients with late radiation nephropathy. Int. J. Radiat. Oncol. 1994, 30, 677-683. [CrossRef]

88. Christopherson, K.M.; Gunther, J.R.; Fang, P.; Peterson, S.L.; Roach, K.E.; Wong, P.-F.; Mirkovic, D.; Lim, T.Y.; Wang, H.; Wang, X.A.; et al. Decreased heart dose with deep inspiration breath hold for the treatment of gastric lymphoma with IMRT. Clin. Transl. Radiat. Oncol. 2020, 24, 79-82. [CrossRef]

89. De Leo, A.N.; Bates, J.E.; Lockney, N.A.; Mendenhall, N.P.; Shaikh, M.E.; Morris, C.G.; Hoppe, B.S. Radiotherapy in Early-stage Gastric MALT. Am. J. Clin. Oncol. 2020, 43, 770-775. [CrossRef]

90. Baron, B.W.; Bitter, M.A.; Baron, J.M.; Bostwick, D.G. Gastric adenocarcinoma after gastric lymphoma. Cancer 1987, 60, 1876-1882. [CrossRef]

91. Shani, A.; Schutt, A.J.; Weiland, L.H. Primary gastric malignant lymphoma followed by gastric adenocarcino-ma. Report of 4 cases and review of the literature. Cancer 1978, 42, 2039-2044. [CrossRef]

92. Ghahremani, G.G.; Fisher, M.R. Lymphoma of the stomach following gastric surgery for benign peptic ulcers. Gastrointest. Radiol. 1983, 8, 213-217. [CrossRef]

93. Zullo, A.; Licci, S. Why does intestinal metaplasia develop early on gastric mucosa of mucosa-associated lymphoid tissue lymphoma patients? Ann. Gastroenterol. 2020, 33, 103. [CrossRef]

94. Griffiths, A.P.; Wyatt, J.; Jack, A.S.; Dixon, M.F. Lymphocytic gastritis, gastric adenocarcinoma, and primary gastric lymphoma. J. Clin. Pathol. 1994, 47, 1123-1124. [CrossRef]

95. De Koster, E.; Buset, M.; Fernandes, E.; Deltenre, M. Helicobacter pylori: The link with gastric cancer. Eur. J. Cancer Prev. 1994, 3 , 247-258. [CrossRef]

96. Kim, S.S.; Ruiz, V.E.; Carroll, J.D.; Moss, S.F. Helicobacter pylori in the pathogenesis of gastric cancer and gastric lymphoma. Cancer Lett. 2011, 305, 228-238. [CrossRef]

97. Au, W.Y.; Gascoyne, R.D.; Le, N.; Viswanatha, D.S.; Klasa, R.J.; Gallagher, R.; Connors, J.M. Incidence of second neoplasms in patients with MALT lymphoma: No increase in risk above the background population. Ann. Oncol. 1999, 10, 317-322. [CrossRef]

98. Xu, Y.; Wang, H.; Zhou, S.; Yu, M.; Wang, X.; Fu, K.; Qian, Z.; Zhang, H.; Qiu, L.; Liu, X.; et al. Risk of second malignant neoplasms after cyclophosphamide-based chemotherapy with or without radiotherapy for non-Hodgkin lymphoma. Leuk. Lymphoma 2012, 54, 1396-1404. [CrossRef]

99. Wang, H.; Milgrom, S.A.; Dabaja, B.S.; Smith, G.; Martel, M.; Pinnix, C. Daily CT guidance improves target coverage during definitive radiation therapy for gastric MALT lymphoma. Pract. Radiat. Oncol. 2017, 7, e471-e478. [CrossRef]

100. Johnson, M.E.; Pereira, G.C.; El Naqa, I.M.; Goddu, S.M.; Al-Lozi, R.; Apte, A.; Mansur, D.B. Determination of planning target volume for whole stomach irradiation using daily megavoltage computed tomographic images. Pract. Radiat. Oncol. 2012, 2, e85-e88. [CrossRef]

101. Reinartz, G.; Haverkamp, U.; Wullenkord, R.; Lehrich, P.; Kriz, J.; Büther, F.; Schäfers, K.; Schäfers, M.; Eich, H.T. 4D-ListmodePET-CT und 4D-CT für die Optimierung des PTV-Sicherheitsabstandes bei Magenlymphomen: Erfassung der intra- und interfraktionellen Magenbewegung. Strahlenther. Onkol. 2016, 192, 322-332. [CrossRef]

102. Hu, W.; Ye, J.; Wang, J.; Xu, Q.; Zhang, Z. Incorporating breath holding and image guidance in the adjuvant gastric cancer radiotherapy: A dosimetric study. Radiat. Oncol. 2012, 7, 98. [CrossRef] [PubMed]

103. Schmelz, R.; Miehlke, S.; Thiede, C.; Brueckner, S.; Dawel, M.; Kuhn, M.; Ruskoné-Formestraux, A.; Stolte, M.; Jentsch, C.; Hampe, J.; et al. Sequential H. pylori eradication and radiation therapy with reduced dose compared to standard dose for gastric MALT lymphoma stages IE \& II1E: A prospective randomized trial. J. Gastroenterol. 2018, 54, 388-395. [CrossRef] [PubMed]

104. Fasola, C.E.; Jones, J.; Huang, D.D.; Le, Q.-T.; Hoppe, R.T.; Donaldson, S.S. Low-Dose Radiation Therapy $(2$ Gy $\times 2)$ in the Treatment of Orbital Lymphoma. Int. J. Radiat. Oncol. 2013, 86, 930-935. [CrossRef] [PubMed]

105. Chan, E.K.; Fung, S.; Gospodarowicz, M.; Hodgson, D.; Wells, W.; Sun, A.; Pintile, M.; Tsang, R.W. Palliation by Low-Dose Local Radiation Therapy for Indolent Non-Hodgkin Lymphoma. Int. J. Radiat. Oncol. 2011, 81, e781-e786. [CrossRef] [PubMed]

106. Ganem, G.; Lambin, P.; Socié, G.; Girinsky, T.; Bosq, J.; Pico, J.L.; Solal-Céligny, P.; Cosset, J.M. Potential role for low dose limited-field radiation therapy ( $2 \times 2$ grays $)$ in advanced low-grade non-Hodgkin's lymphomas. Hematol. Oncol. 1994, 12, 1-8. [CrossRef]

107. Luthy, S.K.; Ng, A.K.; Silver, B.; Degnan, K.O.; Fisher, D.C.; Freedman, A.S.; Mauch, P.M. Response to low-dose involved-field radiotherapy in patients with non-Hodgkin's lymphoma. Ann. Oncol. 2008, 19, 2043-2047. [CrossRef]

108. Haas, R.; Poortmans, P.; de Jong, D.; Verheij, M.; van der Hulst, M.; de Boer, J.; Bartelink, H. Effective palliation by low dose local radiotherapy for recurrent and/or chemotherapy refractory non-follicular lymphoma patients. Eur. J. Cancer 2005, 41, 1724-1730. [CrossRef]

109. Sawyer, E.J.; Timothy, A.R. Low dose palliative radiotherapy in low grade non-Hodgkin's lymphoma. Radiother. Oncol. 1997, 42, 49-51. [CrossRef] 
110. Haas, R.L.M.; Poortmans, P.; De Jong, D.; Aleman, B.M.P.; Dewit, L.G.H.; Verheij, M.; Hart, A.A.M.; Van Oers, M.H.J.; Van Der Hulst, M.; Baars, J.W.; et al. High Response Rates and Lasting Remissions After Low-Dose Involved Field Radiotherapy in Indolent Lymphomas. J. Clin. Oncol. 2003, 21, 2474-2480. [CrossRef]

111. Hoskin, P.; Kirkwood, A.; Popova, B.; Brammer, C.; Diez, P.; Robinson, M.; Syndikus, I.; Jack, A.; Smith, P. FoRT: A Phase 3 Multi-Center Prospective Randomized Trial of Low Dose Radiation Therapy for Follicular and Marginal Zone Lymphoma. Int. J. Radiat. Oncol. 2013, 85, 22. [CrossRef]

112. Knoops, L.; De Jong, D. The role of the p53 pathway in the treatment of follicular lymphoma. Cell Cycle 2008, 7, 436-439. [CrossRef]

113. Knoops, L.; Haas, R.; De Kemp, S.; Majoor, D.; Broeks, A.; Eldering, E.; De Boer, J.P.; Verheij, M.; Van Ostrom, C.; De Vries, A.; et al. In vivo p53 response and immune reaction underlie highly effective low-dose radiotherapy in follicular lymphoma. Blood 2007, 110, 1116-1122. [CrossRef]

114. Kapadia, N.S.; Engles, J.M.; Wahl, R.L. In Vitro Evaluation of Radioprotective and Radiosensitizing Effects of Rituximab. J. Nucl. Med. 2008, 49, 674-678. [CrossRef]

115. Skvortsova, I.; Popper, B.-A.; Skvortsov, S.; Saurer, M.; Auer, T.; Moser, R.; Kamleitner, H.; Zwierzina, H.; Lukas, P. Pretreatment with Rituximab Enhances Radiosensitivity of Non-Hodgkin's Lymphoma Cells. J. Radiat. Res. 2005, 46, 241-248. [CrossRef]

116. Skvortsova, I.; Skvortsov, S.; Popper, B.-A.; Haidenberger, A.; Saurer, M.; Gunkel, A.R.; Zwierzina, H.; Lukas, P. Rituximab Enhances Radiation-Triggered Apoptosis in Non-Hodgkin's Lymphoma Cells Via Caspase-dependent and-Independent Mechanisms. J. Radiat. Res. 2006, 47, 183-196. [CrossRef] 